Bender CJG \& Lombard A

\title{
PERSONAL AND INTERPERSONAL EFFECTS OF A LIFE SKILLS PROGRAMME ON GRADE 7 LEARNERS
}

Dr CJ Gerda Bender is a Senior Lecturer, Department of Curriculum Studies, University of Pretoria and Prof Antoinette Lombard is a Professor, Department of Social Work, University of Pretoria.

\section{INTRODUCTION}

Life skills education covers the skills and competencies that an individual needs for sustaining and enriching life and also the kind of behaviour-based learning that the individual needs for coping with predictable developmental tasks (Adkins, 1984:53-54; Pickworth, 1989:105: Schmidt, Brown \& Waycott, 1988:13). The central reason for including life skills education in the school curriculum is that an interventional, preventive and developmental approach to equipping schoolchildren (learners) with coping skills will help them to deal effectively with predictable developmental tasks and an ever-changing world (Department of Education, 1997a).

Life skills are indispensable to the process of empowering individuals to engage in and cope successfully with life and its challenges. This is seen as imperative in societies which are still developing, such as South Africa (De Jong, Ganie, Lazarus \& Prinsloo, 1995:93). The development of life skills promotes psychosocial competence. Life skills education enhances an individual's coping resources by promoting personal and interpersonal (social) competence and confidence (Donald, Lazarus \& Lolwana, 1999:96). Life skills may be defined broadly as not only the skills but also the insight, awareness, knowledge, values, attitudes and qualities that are necessary to empower individuals and their communities to cope and engage successfully with life and its challenges in South African society.

The development and implementation of a curriculum for life skills education in schools should be understood in the overall context of the development of education support services, namely social work, school health, specialised education, vocational and general guidance and counselling, and psychological services. The life skills curriculum in schools is also underpinned by the principle of service integration: that is, emphasising the need to view issues of development as interrelated. This principle requires an interdisciplinary approach to curriculum development and implementation, including all the above-mentioned education support services (De Jong et al., 1995:92-93). Service agencies near to the school are regarded as part of the community and therefore as members of the outcomes-based education team (Department of Education, 1999:13-16).

Curriculum 2005 is a new education curriculum driving the process of education transformation in South Africa. Curriculum 2005 is an outcomes-based curriculum with a special emphasis on integration of the eight learning areas, namely Arts and Culture; Economic and Management Sciences; Human and Social Sciences; Language, Literacy and Communication; Life Orientation; Mathematics, Mathematical Literacy and Mathematical Sciences; Natural Sciences and Technology. Besides changes in education, Curriculum 2005 has also resulted in structural and organisational changes. These changes are partly due to the fact that all of Education and Training, and hence Curriculum 2005, forms part of the National Qualifications Framework (NQF). Curriculum 2005 is organised into "areas of learning" that serve as the basis for developing learning programmes. Life skills education has been formally included in all school curricula since 
1996, but real efforts have to be made to make life skills education more accessible. Life skills education is a fundamental division of the Learning Area: Life Orientation. Life Orientation empowers learners to live meaningful lives in a society that demands rapid transformation. Life Skills Programmes should be designed to promote the vision of Curriculum 2005 and to enable the facilitators (social workers) to implement an outcomes-based educational approach. The social worker can be an initiator of life skills education and his/her work may become the model on which further life skills education is based. This is important not only for South Africa, but also for the rest of the world. There is a universal interest in and need for life skills education (Rooth, 1997:2). As school social work is part of the proposed model of education support services, as set out in Donald \& Lazarus (1995), it has been regarded as an essential support service to education.

Tshiwula (1995) points out that because social workers have the training, knowledge and experience in working with individuals, groups and communities, they are in a position to provide meaningful direction to the work done in schools. The social worker is an important link between the school, the learner, the family and the community. Since the social worker takes part in strategies for intervention, prevention and development, he/she can contribute to developing life skills programmes that will foster the personal and interpersonal development of learners. Life skills education should include skills in developing self-awareness, communication and assertiveness skills, skills in interpersonal relationships and problem solving (McKendrick \& Hoffmann, 1990; Tshiwula, 1995). In a broader sense, Tshiwula (1995) recommends that schools should ask social workers to run context-specific programmes which could help to prevent problems such as truancy, vandalism, substance abuse and juvenile delinquency. The researchers also believe that social workers ought to be involved in developmental programmes, such as developing and implementing various life skills programmes. In addition, Delva-Tauili'ili (1995:86) stresses the important roles of social work in encouraging sensitivity to the individual's cultural and social experiences, and in preparing teachers and learners to meet the needs of an increasingly multicultural school population. Social workers should actively develop interventions that include the entire school system.

Society pays a high price when children and young people lack social and emotional competence. Social competence refers to the ability to establish acceptable and productive relationships with other people. It has been linked with many areas of success in adulthood, such as vocational competence, active involvement and participation in community development, marital satisfaction and parenting socially adjusted children. A strong and growing body of research also links intrapersonal and interpersonal functioning in childhood and adolescence to a wide variety of life outcomes, including academic functioning, social functioning, school drop-out, teen pregnancy, juvenile delinquency and mental health problems (Bruene-Butler, Hampson, Elias, Clabby \& Schuyler, 1997:239-240).

The majority of children in South Africa do not have the opportunity to learn life skills from their families. Poverty, migratory labour, poor or no housing and long distances from the workplace are a few of the destructive forces that have affected the family life of black South Africans over many decades (Viljoen, 1994:91). It is the school, rather than parents, that is now responsible for helping these children to develop and learn life skills.

Rooth (1997:28) believes that the importance of life skills education in the primary school cannot be stressed enough. Life skills education in the primary school is developmental, promotive and preventive. Children who have access to life skills education will learn the skills they need to cope with the problems of growing up. It is difficult to begin life skills education at secondary school if the important groundwork has not been done at primary school. Life skills development is a lifelong process. 
Primary school children, or rather children in the General Education and Training Band (preschool; foundation phase; intermediate and senior phase), can become more self-empowered by learning life skills. Social workers, teachers, psychologists and parents could be modelling growthoriented values, and help children become more aware of their inner and external worth, by giving them information and by helping them to develop goals and commitments. They could also work at changing the schools and other institutions into empowering rather than depowering places to live and work (compare Hopson \& Scally, 1986:79).

The research was motivated by the fact that:

- There are no guidelines for the social worker to develop/design life skills programmes for senior phase learners, although this would promote the vision of Curriculum 2005;

- There are no guidelines for the social worker to implement or present a life skills programme for the senior phase learners, based on an outcomes-based educational approach;

- Social workers present various life skills programmes at different primary and secondary schools without evaluating or assessing the effectiveness of the programmes.

The main objective of the study was to develop and implement an outcomes-based life skills programme for Grade 7 learners of a traditionally African school, and to evaluate whether participation in the life skills programme would lead to personal growth (self-empowerment) and social competence and thus contribute to the optimal social functioning of children in the classroom, school, family and community (capacity building). This research attempts to determine the effects of this outcomes school-based intervention programme on the personal and interpersonal development of learners in the senior phase

The present study included learners in Grade 7 of the senior phase of the General Education and Training Band (GET). This is the final year of primary school. These children (learners) are in the developmental stage of late childhood to early adolescence. The ages of the learners included in the study varied from 12 to 16 years, due to progressive mainstreaming, and therefore the study focuses on the adolescent. Adolescence is the time in which the individual re-evaluates and discovers new aspects about him/herself, adapts his/her self-image and gains a new perception of his/her identity due to the discovery of his/her new self. Adolescence is characterised by moving away from the child's body, life perceptions and behaviour patterns. It is important to note that the primary developmental needs and tasks of the adolescent in the senior phase should be related to the needs and tasks associated with the previous phases and be contextually sensitive to the diverse cultures of the South African school population.

\section{RESEARCH PROBLEM}

The main research problem reported on here was the following: what effects does a Life Skills Programme have on the personal and interpersonal development of learners in the senior phase?

Subsidiary problems emanating from the main problem revolved around the effectiveness of the life skills programme by determining whether it:

- contributed to the learner's self-knowledge, knowledge of feelings, thinking, actions, needs, responsibilities, feelings of self-worth, positive attitudes towards the self (enhancement of self-concept and self-reliance: personal);

- contributed to the learner's knowledge and understanding of his/her family, school, friends, community; developed more effective communication, problem-solving and conflict 
management skills (empowerment, capacity-building) and in addition had an impact on the learner's participation in the classroom, school and community (interpersonal).

\section{RESEARCH HYPOTHESIS}

In view of the preceding statement of the problem, this research is directed further by the following overarching hypothesis: the Life Skills Programme has a statistically significant influence on the personal and interpersonal development of the Grade 7 learners.

\section{THE LIFE SKILLS PROGRAMME AND SPECIFIC OUTCOMES}

The aim of the Life Skills Programme for Grade 7 learners is to foster positive behaviours across the range of psycho-social skills, and to change unacceptable behaviours learned early in life, which may translate into inappropriate and risky behaviour at a later stage of life. Therefore the main aim of the programme is that the intervention (programme) should lead to personal growth (self-empowerment) and social competence, and contribute to the optimal social functioning of children in the classroom, school, family and community (capacity building). The focus is on outcomes-based learning, which is learning that is based on intended end-results, as opposed to traditional input-based learning. It is based on what a learner wants to or should achieve and then working backwards to determine what is needed to achieve it (Olivier, 2001).

The Life Skills Programme of this study falls under the Learning Area: Life Orientation which includes the building of self-esteem of learners, acquiring survival skills and a healthy lifestyle. Learning programmes are the vehicles through which Curriculum 2005 is implemented. The programmes serve as guidelines that enable the facilitators to engage in outcomes-based learning interventions. For each of the eight areas of learning specific outcomes were identified that define supportive or embedded knowledge, skills and values needed to be covered at specific school grades (Olivier, 2001). The specific outcomes serve as the basis to plan learning programmes and experiences. An outcomes-based learning programme design was implemented in the design of the

Life Skills Programme of this study. The following specific outcomes (SO) were used for designing and implementing the programme:

- SO1: Understand and accept themselves as unique and worthwhile human beings. Life Orientation is instrumental in promoting a meaningful lifestyle for each learner. This specific outcome aims at developing respect for the self, which includes a positive self-concept and self-actualisation. This will be attained by

- promoting the individual's own worth, dignity and rights as a unique individual;

- examining how the physical and social environment affects personal development and growth;

- exploring the role of social, cultural and national perspectives in shaping personal attitudes and values; and

- understanding the integrated nature of the whole person.

- SO2: Use skills and display attitudes and values that improve relationships in family, groups and community.

- SO3: Respect the rights of people to hold personal beliefs and values.

- SO4: Demonstrate value and respect for human rights as reflected in Ubuntu and other philosophies. 
- SO5: Practise acquired life skills and decision-making skills.

- SO6: Assess career and other opportunities and set goals that will enable them to make the best use of their potential and talents.

- SO7: Demonstrate the values and attitudes necessary for a healthy and balanced life style.

- SO8: Evaluate and participate in activities that demonstrate effective human movement and development (Department of Education, 1997b).

\section{TABLE 1}

OUTLINE OF THE LIFE SKILLS PROGRAMME

\begin{tabular}{|c|c|}
\hline \multicolumn{2}{|c|}{ Phase organisers: $\quad$ Personal Development and Empowerment } \\
\hline \multicolumn{2}{|c|}{ Programme organiser: $\quad$ Personal and Interpersonal Development } \\
\hline \multicolumn{2}{|c|}{ Programme presenter: } \\
\hline \multicolumn{2}{|c|}{ Guidance teacher: } \\
\hline \multicolumn{2}{|c|}{ Objective observer: } \\
\hline \multicolumn{2}{|c|}{ Learners: Grade 7} \\
\hline Duration: & \pm 15 Sessions, $\pm 1 \frac{1}{2}$ hour per session \\
\hline GOAL: & PERSONAL AND INTERPERSONAL DEVELOPMENT \\
\hline Session & THEME \\
\hline $\begin{array}{l}\text { Session: } \\
\text { Introduction }\end{array}$ & $\begin{array}{l}\text { Building relationships. } \\
\text { Questionnaire on needs assessment for learners. }\end{array}$ \\
\hline $\begin{array}{l}\text { Session: } \\
\text { Introduction }\end{array}$ & $\begin{array}{l}\text { Pre-test: Baseline assessment: Questionnaire for participants/learners } \\
\text { Programme orientation; Knowledge of the South African context and why } \\
\text { we want to develop our life skills; Building relationships }\end{array}$ \\
\hline Session 1 & $\begin{array}{l}\text { Life skills } \\
\text { Developing self-awareness, self-knowledge and sensory contact (SELF) }\end{array}$ \\
\hline Session 2 & My family and me \\
\hline Session 3 & My school, friends and me \\
\hline Session 4 & Dating and interpersonal relationships \\
\hline Session 5 & My community and me \\
\hline Session 6 & Needs, rights and responsibilities \\
\hline Session 7 & Rainbow nation, first impressions and stereotyping \\
\hline Session 8 & Effective communication \\
\hline Session 9 & Problem solving \\
\hline Session 10 & Conflict resolution \\
\hline Session 11 & Death: grieving and growing \\
\hline Session 12 & Where do I go for help /counselling? \\
\hline Final session & $\begin{array}{l}\text { EVALUATION OF THE PROGRAMME. } \\
\text { Post-test: Questionnaire for participants/learners } \\
\text { Week after termination: Evaluation }\end{array}$ \\
\hline
\end{tabular}


The Life Skills Programme includes the following themes: Developing self-awareness, selfknowledge of self and sensory contact; My family and me; My school and me; Dating and interpersonal relationships; My community and me; Needs, rights and responsibilities; Rainbow nation, first impressions and stereotyping; Effective communication; Problem solving; Conflict resolution; Death: grieving and growing; and Where do I go for help? Table 1 gives an outline of the outcomes-based programme.

The researchers adapted and adjusted Rooth's model of life skills education (1997), consisting of facilitation, group work, experiential learning and continuity, for the implementation of the programme. Various facilitation media or methods were used. Table 2 gives an outline of each of the sessions.

TABLE 2

SESSION OUTLINE FOR THE LIFE SKILLS PROGRAMME

\begin{tabular}{|c|c|c|c|c|c|c|c|}
\hline \multicolumn{8}{|c|}{ THEME } \\
\hline \multicolumn{8}{|c|}{ Programme Organiser: } \\
\hline \multicolumn{8}{|c|}{ SO $=$ Specific outcomes } \\
\hline SO1 & $\mathrm{SO} 2$ & $\mathrm{SO} 3$ & $\mathrm{SO} 4$ & SO5 & SO6 & SO7 & SO8 \\
\hline \multicolumn{8}{|c|}{ LEARNING OUTCOMES (OBJECTIVES) } \\
\hline \multicolumn{8}{|c|}{ RESOURCES } \\
\hline \multicolumn{8}{|c|}{$\begin{array}{l}\text { ICE-BREAKER AND SENSORY ACTIVITY } \\
\text { - Sensory activity } \\
\text { - } \quad \text { Beginning: Self-awareness: my senses: smell, hear, taste, touch and see. }\end{array}$} \\
\hline \multicolumn{8}{|c|}{ ACTIVITY - EXPERIENTIAL LEARNING (PROCESS) } \\
\hline \multicolumn{8}{|c|}{ DISCUSSION AND FEEDBACK } \\
\hline \multicolumn{8}{|c|}{ REMARKS / COMMENTS / REFLECTION } \\
\hline \multicolumn{8}{|c|}{ SELF-NURTURING } \\
\hline REST & CES Us & $\mathrm{OR} \mathrm{PF}$ & $\overline{\mathrm{ATI}}$ & & & & \\
\hline
\end{tabular}

\section{RESEARCH METHODOLOGY}

\section{The research design}

A descriptive design with a quasi-experiment, one-group pre-test-post-test experiment, was used. The quasi-experimental design is characterised by a single sample of participants who are exposed to some or other treatment or experimental intervention (to which they would not have been subjected in the normal course of events) (Huysamen, 1994:51). The one-group pre-test-post-test design is also referred to as a before-and-after design because it includes a pre-test of the dependent variable, which can be used as a basis of comparison with the post-test results. The researcher therefore used what Grinnell and Williams (1990:160) refer to as a descriptive pre-test and post-test design.

The pre-test (questionnaire where Grade 7 learners had to rate their personal and interpersonal life skills on an ordinal scale of 0 to 3) was administered. The Life Skills Programme was implemented. The post-test (questionnaire where Grade 7 learners had to rate their personal and interpersonal life skills on an ordinal scale of 0 to 3) was administered. There was also a sessionby-session evaluation questionnaire to be completed by learners in order to improve the 
effectiveness of the programme continuously. Lastly, a questionnaire on the evaluation of the programme (usefulness; importance of different modules for participants; methods used; usefulness for personal and interpersonal growth and social competence; most important life skills learnt) was administered (Participant retrospective evaluation questionnaire).

\section{The participants}

The sample being studied was comprised of all the Grade 7 learners at a primary school in a township east of Pretoria. It is a traditionally black primary school and the learners' mother tongue is mainly Tsonga. There were 40 learners in the only Grade 7 class and their ages varied from approximately 12 to 16 years.

A non-probability sampling procedure was employed, namely that the probability of inclusion in the sample would involve the convenience and availability of the participants. Marlow (1993) adds that non-probability sampling has been frequently employed in social work research and in evaluating social work practice. With non-probability sampling there is limited support for the claim that the sample is representative of the population from which it is drawn (Gabor, 1993; Patton, 1990). However, this was not a major concern of the present study since its aim was to design, develop and improve an outcomes-based programme for effectiveness in a specific context.

As this was a non-probability or non-randomised sampling method, it is recognised that generalisation should be done with caution, as the sample may not necessarily be representative of early adolescents in general. Therefore it should be stated that any significant findings would be significant for this particular group of learners.

\section{THE INSTRUMENTS}

The Life Skills Programme, which was divided into two sections: the Personal and Interpersonal Life Skills, was implemented over twelve sessions lasting about one-and-a-half hours each, held twice weekly over a period of six weeks. In addition there were three other sessions: two orientation sessions at the beginning and a termination session at the end of the programme. As suggested by Corey and Corey (1992), time was set aside at the end of each session to enable participants to complete the evaluation questionnaires. It should be noted that during the termination session (session 15), the facilitator engaged the participants in the process of summarising and reflecting on the lessons they had learned during the previous sessions, followed by the overall evaluation of the programme. The programme was implemented in a large group (40 learners in the classroom), which was divided into 6 smaller groups consisting of 5 to 7 learners. The researchers considered the group work method as appropriate because it was in keeping with the ecological paradigm. The researchers used the definition of group work given by Thackeray, Farley and Skidmore (1994:73) as a frame of reference because a personal and interpersonal life skills programme was implemented: “...a method of working with people in groups for the enhancement of social functioning and for the achievement of socially desirable goals. Group work is based on the knowledge of people's needs for each other and their interdependence. Group work is a method of reducing or eliminating roadblocks to social interaction and for accomplishing socially desirable purposes".

In keeping with this definition, Drower (1993) stresses the need to use groups to address the connection between the individual and the social context. Breton (cited in Drower, 1993) draws attention to the fact that coping and finding fulfilment in a changing world requires an awareness that one's own self-interest is linked to the welfare of the larger ecological system. 
Group work as method was therefore considered relevant and enlightening because social workers are used to working with small group contexts (8-12 participants, according to Corey \& Corey, 1992:319-320). Moreover in the school context it is expected that the social worker will include all learners in the classroom and the number of learners may vary from 28-50. These learners could be divided into smaller groups and the group work method could be implemented as illustrated by this study.

\section{- Participant pre-test and post-test questionnaire}

The pre-test measures provided a baseline for gauging the changes in participant responses (Pietrzak, Ramler, Renner, Ford \& Gilbert, 1990). Furthermore, in keeping with the objectives of the study, the research design helped to ascertain whether minimum standards of programme outcome had been achieved and the extent to which participants changed during their participation in the programme (Marlow, 1993). Fitz-Gibbon and Morris (1987) state that, depending on the nature of the study, the absence of a comparison group for judging outcomes may be problematic. However, these authors add that this design was suitable in studies that focused on monitoring programme implementation. As programme design and implementation were objectives of the study, the design was regarded as appropriate. The choice of design ought to be viewed against the total triangulation of the methodology in this study. This instrument, Participant pre-test and posttest questionnaire, was one of several data-gathering instruments used to measure the impact that the programme might have had on the participants.

The questionnaire consisted of two sections of statements about personal and interpersonal life skills. The participants were asked to read the sentence and put a tick $(\sqrt{ })$ at the number that showed how they rated their life skills. Therefore the participants had to rate or assess their life skills on an ordinal scale from 0 to $3(0=$ no need for improvement; $1=$ slight need for improvement; $2=$ moderate need for improvement and $3=$ much need for improvement). Jordon, Franklin and Corcoran (1993) indicate that self-ratings are helpful because individuals can evaluate their own thoughts, behaviour and feelings accurately, provided that they are self-aware and willing to be truthful. This questionnaire was also in line with guidelines on outcomes-based assessment with the focus on self-assessment (Department of Education, 2002). Some of the statements relate to what Patton (1987) describes as "feeling" questions, which are aimed at understanding the emotional responses of people to their experiences and thoughts. Other statements can be described as experience/behaviour questions, which are aimed at eliciting descriptions of the experiences, behaviours, actions and activities of persons in the face of certain situations. All the items of the questionnaires are learning outcomes as formulated for the themes (sessions) of the Life Skills Programme. The researchers view the pre-test as relating to the baseline assessment in outcomes-based education. Baseline assessment is used at the beginning of a new set of learning activities (in this study the Life Skills Programme). Baseline assessment is carried out so as to find out what the learners already know and can demonstrate, so that a decision can be taken on what level of demands should be built into the learning experience plan (Department of Education, 2002).

This instrument was administrated individually, in this way giving the facilitator and objective observer a good deal of control in explaining the purposes of the questions and responses. The instrument was tested in terms of its face and content validity among a small random sample of Grade 7 learners attending three primary schools in Pretoria and also during the pilot study. The instrument was then modified in accordance with the problems encountered during its trial use. The Participant pre-test and post-test questionnaire was administered during the orientation session and then a week after the termination of the programme. 
- $\quad$ Participant retrospective evaluation questionnaire

Retrospective evaluation was undertaken a week after the termination of the programme and a day after the post-test. A final evaluation questionnaire was developed to obtain the feelings and opinions of participants about their experiences of the Life Skills Programme. A written explanation of the purpose of the questionnaire was included in the instrument, because the participants had a right to know why they were being questioned (King, Morris \& Fitz-Gibbon, 1987).

\section{STATISTICAL METHOD USED}

A non-parametric statistical test was utilised for the present study, because the data were measured on an ordinal scale. As non-parametric tests are generally designed for the analysis of nominal or ordinal level data, they are often ideally suited for use in social work research (Weinbach \& Grinnell Jr, 1998: 114).

Although the virtues of non-parametric tests have been much debated, those who favour using non-parametric tests argue that they have most of the virtues of traditional parametric tests, without the possible distortions that may arise if assumptions are violated. However, one disadvantage is that non-parametric methods tend to focus exclusively on null hypothesis testing. The goal of model fitting, obtaining confidence intervals and so forth is set aside in favour of tests of significance (Lockhart, 1997:554). This did not prove to be a handicap in the present research study, as hypothesis testing was exactly what the researchers wanted to do. The null hypothesis for the study was: there is no improvement in the participants' pre-test and post-test questionnaire scores. The alternative hypothesis was: there is an improvement in the participants' pre-test and post-test questionnaire scores.

The Wilcoxon signed-rank test was used in this research (Daniel \& Terrell, 1995:723; Weinbach \& Grinnell Jr, 1998:221-222). This is a well-established non-parametric procedure that is often used for one-sample cases. The test is useful to the behavioural scientist because it enables the researcher to make the judgement of "greater than" between the two values of any pair, as well as between any two "difference scores" arising from any two pairs (Siegel \& Castellan, 1988:87). Whereas the sign test uses information only about the direction of the differences within pairs, the Wilcoxon signed-rank test gives more weight to a pair that shows a large difference between the two conditions than to a pair which shows a small difference (Siegel \& Castellan, 1988:87). The Wilcoxon signed-rank test was chosen because the study employed two paired samples and it yielded difference scores, which could be ranked in order of absolute magnitude (Siegel \& Castellan, 1988:90). This test determines whether or not the data imply that the population distribution of scaled responses is the same for the group in the before testing as in the after testing. The differences are ranked according to their absolute values from smallest to largest; whenever the rank sums for negative and positive differences depart considerably from their expected values, the hypothesis of no difference is rejected. Substantial departures indicate a difference from the expected value and provide evidence that differences exist (Jarrett \& Kraft, 1998:607; Lockhart, 1997:555; Steyn, Smit, Du Toit \& Strasheim, 1994:15).

To extend the evaluation of the effectiveness of the Life Skills Programme (contents and media used), an evaluation questionnaire was compiled by the researchers and completed by the participants (Grade 7 learners/ senior phase learners). A frequency analysis was done on these data, as summarised in Tables 5, 6 and 7. 


\section{RESULTS OF THE INVESTIGATION}

- Personal life skills: Participant Pre-test and Post-test Questionnaire (Figure 1)

Forty participants completed the pre-test and post-test. It should be noted that although the researchers distinguish between the Personal and Interpersonal sections of the Life Skills Programme, they are inseparable. It is only for scientific reasons that the researchers distinguish between these sections. The improvement from the pre-test to the post-test scores for the different items was calculated for each learner. The mean improvement scores for the whole group and both genders are given in Figure 1.

The Grade 7 learners (girls/females, boys/males and total group) had an overall gain in the points they scored, an improvement ranging between 0 and 3 points. The total increase in all the items of the Personal Life Skills Programme was highly significant (as indicated by the signed-rank test of Wilcoxon) for the girls, boys and total group $(\mathrm{p} \leq 0,01)$. The girls showed a greater improvement in their personal life skills than the boys. The following 3 items of the Personal Life Skills Programme indicated the greatest improvement for the girls: Knowing myself (Item 1); Knowing my actions and acknowledging the importance of my feelings (Items 4 and 9) and My feelings (Item 2). The items indicating the lowest improvement (although still highly significant) were: Need to build positive attitudes toward myself (Item 11) and To influence what happens to me (Item 12) (see Figure 1).

FIGURE 1

PERSONAL LIFE SKILLS: FEMALES, MALES AND TOTAL GROUP

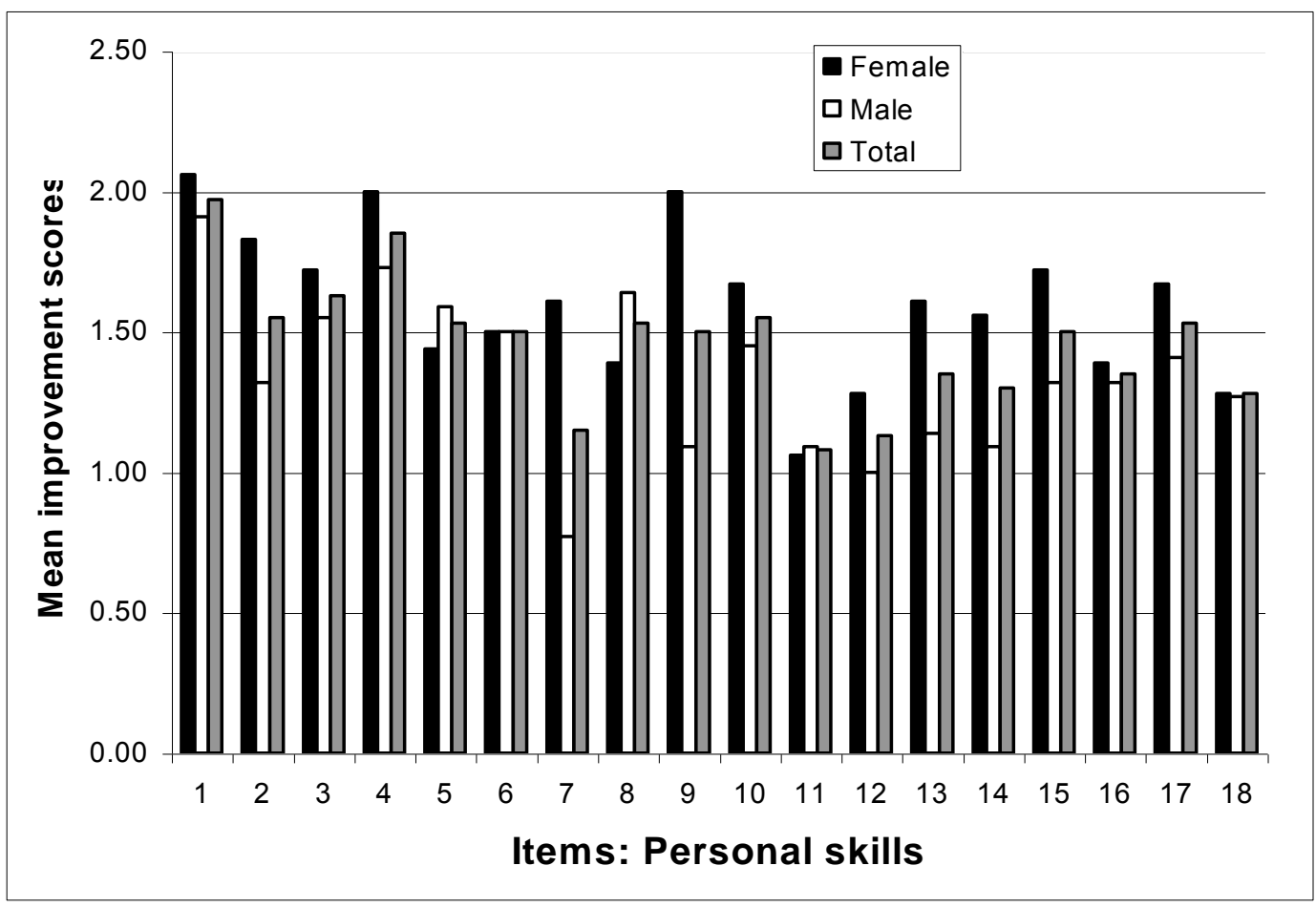


The following three items of the Personal Life Skills Programme indicated the highest improvement for the boys: Knowing myself (Item 1); Knowing my actions (Item 4) and Sharing personal information (Item 8). The items indicating the lowest improvement (although still highly significant) were: Awareness of my wants and wishes (Item 7), and To influence what happens to me (Item 12) (see Figure 1).

As regards the total group, the following three items of the Personal Life Skills Programme indicated the highest improvement: Knowing myself (Item 1); Knowing my actions (Item 4) and Knowing my thinking (Item 3) (see Figure 1). The following two items showed the lowest improvement (although still highly significant): Need to build positive attitudes toward myself (Item 11), and To influence what happens to me (Item 12) (see Figure 1).

- Interpersonal life skills: Participant Pre-test and Post-test Questionnaire ( Table 3)

The improvement from the pre-test to the post-test scores for the different items was calculated for each learner. The mean improvement scores for the whole group and each gender are given in Table 3. The Grade 7 learners (girls/females, boys/males and total group) had an overall gain in points, an improvement ranging between 0 and 3 points. The total increase in all the items of the Interpersonal Life Skills Programme was highly significant (as indicated by the signed-rank test of Wilcoxon) for the girls, boys and total group $(\mathrm{p} \leq 0,01)$. The girls indicated more improvement on their interpersonal life skills than the boys. The following three items of the Interpersonal Life Skills Programme indicated the highest improvement for the girls: To know how to date and develop relationships with the opposite sex (Item 24); Know how to start and develop relationships (Items 22 and 23) and To know and understand my school and To know and understand my friends (Items 20 and 21). The item with the lowest improvement (although still highly significant) was: To know where I can go for help/guidance/counselling (Item 37) (see Table 3).

TABLE 3

INTERPERSONAL LIFE SKILLS: MEAN IMPROVEMENT SCORES

\begin{tabular}{|l|c|c|c|}
\hline Item & Female & Male & Total \\
\hline 19: My family & 1,72 & 1,59 & 1,65 \\
\hline 20: My school & 1,89 & 1,55 & 1,70 \\
\hline 21: My friends & 1,89 & 1,41 & 1,63 \\
\hline 22: Starting relationships & 1,94 & 1,55 & 1,72 \\
\hline 23: Developing relationships & 1,94 & 1,68 & 1,80 \\
\hline 24: Dating and opposite gender & 2,33 & 1,14 & 1,67 \\
\hline 25: My community & 1,89 & 1,36 & 1,60 \\
\hline 26: Contribute: School and Community & 1,44 & 1,18 & 1,30 \\
\hline 27: Rainbow nation & 1,56 & 1,59 & 1,58 \\
\hline 28: Differences in people & 1,44 & 1,50 & 1,47 \\
\hline 29: Effective communication & 1,78 & 1,32 & 1,53 \\
\hline 30: Listener & 1,56 & 1,32 & 1,42 \\
\hline 31: Speaker & 1,89 & 1,73 & 1,80 \\
\hline 32: Solve problems & 1,72 & 1,36 & 1,53 \\
\hline 33: Share, communicate, trust people & 1,50 & 1,36 & 1,42 \\
\hline 34: Managing conflict & 1,44 & 1,36 & 1,40 \\
\hline 35: Managing anger & 1,72 & 1,41 & 1,55 \\
\hline 36: Death and grieving & 1,67 & 1,45 & 1,55 \\
\hline 37: Guidance /counselling & 1,33 & 1,36 & 1,35 \\
\hline
\end{tabular}


The following three items of the Interpersonal Life Skills Programme indicated the highest improvement for the boys: To be able to be a good speaker (Item 31); Developing relationships (Item 23); and To know and understand my family and To know and understand our rainbow nation (Items 19 and 27). The items indicating the lowest improvement (although still highly significant) were: To know how to date and develop relationships with the opposite sex (Item 24) and To know how can I contribute to developing my school and community (Item 26) (see Table 3).

As regards the total group, the following three items of the Interpersonal Life Skills Programme indicated the highest improvement: Developing relationships and To be able to be a good speaker (Items 23 and 31); Starting to build relationships (Item 22) and To know and understand my school (Item 20). The following item had the lowest improvement (although still highly significant): To know how can I contribute to developing my school and community (Item 26) (see Table 3).

- $\quad$ Participants' retrospective evaluation questionnaire (Tables 4 and 5)

This section provides an analysis and discussion of the data obtained from the questionnaires, which assessed participants' retrospective evaluation of all the sessions (the whole programme) and of the total group (females and males together). The purpose was to obtain the participants' overall impressions and recommendations regarding the Life Skills Programme (Personal and Interpersonal). These findings were compared with the findings of the session-by-session evaluations. Supplementary data were also obtained from the evaluation reports given by the objective observer and the guidance teacher. Their reports were submitted after the completion of the programme. As advocated by Bryman (1990), Cheetham, Fuller, McIvor and Petch (1992), Harrison (1994) and Patton (1987), an analysis of information derived from different sources allowed for checks across the data gathered and enhanced the validity of the findings.

Table 4 provides a summary of the extent to which the themes used during programme implementation were useful to the participants.

TABLE 4

USEFULNESS OF THEMES FOR PARTICIPANTS (N=40)

\begin{tabular}{|l|c|c|c|c|}
\hline \multirow{2}{*}{ THEMES } & \multicolumn{3}{|c|}{ RESPONSES } \\
\cline { 2 - 5 } & YES & $\boldsymbol{\%}$ & NO & $\%$ \\
\hline 1. Me (Self-knowledge) & 39 & 98 & 1 & 2 \\
\hline 2. My family and me & 33 & 83 & 7 & 17 \\
\hline 3. My school, friends and me & 33 & 83 & 7 & 17 \\
\hline 4. Dating and relationships with opposite sex & 23 & 58 & 17 & 42 \\
\hline 5. My community and me & 37 & 93 & 3 & 7 \\
\hline 6. Needs, rights and responsibilities & 33 & 83 & 7 & 17 \\
\hline 7. Rainbow nation, first impressions and stereotyping & 32 & 80 & 8 & 20 \\
\hline 8. Effective communication & 34 & 85 & 6 & 15 \\
\hline 9. Problem solving & 31 & 78 & 9 & 22 \\
\hline 10. Conflict and conflict resolution & 29 & 73 & 11 & 27 \\
\hline 11. Death: grieving and growing & 27 & 68 & 13 & 32 \\
\hline 12. Where can I go for help? & 32 & 80 & 8 & 20 \\
\hline
\end{tabular}


Table 4 indicates that $98 \%$ of the participants stated that Theme One of the programme: Developing self-awareness and self-knowledge (personality, thoughts, feelings, behaviour, capabilities, self-concept) was the most useful to them (Theme 1). These responses indicated that the overall learning outcomes of the programme were achieved. These data are congruent with the data obtained from the pre-test and post test (see Figure 1). Regarding Theme 5: My community and me, $93 \%$ of the learners indicated that the session was useful to them. From the findings shown in Table 4, $85 \%$ of the learners indicated that Theme 8: Effective communication, was useful to them. As regards Theme 2 (My family and me); Theme 3 (Me, my school and friends) and Theme 6 (Needs, rights and responsibilities), 83\% of the participants indicated that these themes or sessions were useful to them. These data are congruent with the data obtained from the participants' session-by-session evaluations and were further confirmed by the objective observer's and guidance teacher's observations and reports. These responses indicated that the overall specific outcomes of the programme were achieved.

In response to the question asking the participants to select the six themes that were most important to them, they indicated the following in order of priority: Self-knowledge; Me and my family; Me and my school and friends; Effective communication; Rainbow nation, first impressions and stereotyping; and Needs, rights and responsibilities.

Table 5 provides a summary of the extent to which the methods or media of facilitation used during the programme implementation were useful to the participants.

TABLE 5

USEFULNESS OF FACILITATION METHODS FOR PARTICIPANTS (N=40)

\begin{tabular}{|l|l|l|l|l|}
\hline METHODS USED & YES & $\%$ & NO & $\%$ \\
\hline 1. General discussions & 29 & 73 & 11 & 17 \\
\hline 2. Group discussions & 29 & 73 & 11 & 17 \\
\hline 3. Role playing & 21 & 53 & 19 & 47 \\
\hline 4. Drama & 28 & 70 & 12 & 30 \\
\hline 5. Exercises in workbook & 26 & 60 & 14 & 40 \\
\hline 6. Case study & 22 & 55 & 18 & 45 \\
\hline 7. Music and movement & 24 & 60 & 16 & 40 \\
\hline 8. Drawings & 24 & 60 & 16 & 40 \\
\hline 9. Clay & 28 & 70 & 12 & 30 \\
\hline 10. Seeds & 22 & 55 & 18 & 45 \\
\hline 11. Pictures from magazines, news papers and handouts & 29 & 73 & 11 & 17 \\
\hline 12. Pictures and notes/ handouts for own books (pasting) & 28 & 70 & 12 & 30 \\
\hline 13. Making posters for the classroom & 28 & 70 & 12 & 30 \\
\hline 14. Sensory activities (taste, smell, see, hear, touch) & 26 & 60 & 14 & 40 \\
\hline
\end{tabular}

Table 5 indicates that the use of general discussions in the large group, discussions in the small or sub-groups ( 5 to 7 learners) and pictures selected form magazines, newspapers and handouts about the theme (session) as facilitation methods received the greatest support from the participants ( $73 \%$ for Items 1, 2 and 11). Seventy percent of the participants indicated that they also supported the following methods or media of facilitation used during the implementation of the programme: Drama; The use of clay to make objects (for example, build their own school or community); Pictures and notes (worksheets) for their workbook and making posters for the classroom (Items 4, 
9, 12 and 13). The participants indicated a lower preference for role playing (Item $3=53 \%$ ) and the use of different seeds to create pictures (Item $10=55 \%$ ).

\section{DISCUSSION OF THE RESULTS}

The study was designed to test the hypothesis that Grade 7 learners who participated in an intervention programme (an outcomes-based life skills programme) would exhibit more personal growth (personal life skills) and social competence and thus contributes to the optimal social functioning of the learners in the classroom, school, family and community (interpersonal life skills). The findings of the investigation indicated that the null hypothesis should be rejected because the improvement in the pre-test post-test questionnaire scores was highly significant (all items $=\mathrm{p}$ value $\leq 0,01)$. Therefore, the Life Skills Programme had a statistically highly significant effect on the personal and interpersonal life skills development of the Grade 7 learners in the senior phase of the General Education and Training Band in this particular primary school.

These findings were consistent with the information obtained from the participants' retrospective evaluation of the programme However, caution should be exercised in generalising the findings and conclusions from the statistical tests to a wider population. The first exposure of the learners or participants to an outcomes-based life skills programme presented at their school might have influenced their responses. As mentioned elsewhere, there was no control or comparison group against which to judge the outcomes of the programme. Furthermore, the nature of the study may have introduced a bias toward what the participants regarded as favourable. They may have developed positive responses in accordance with perceived expectations. It should be noted that the participants had been involved in a needs assessment regarding life skills and they identified the priority of the themes. The learners therefore took ownership of the programme. In this way one of the basic community development principles, namely getting the community involved and letting them take ownership of the programme, could be explained and illustrated.

Efforts to secure the interests of parents by requesting their co-operation and support may have contributed to the positive attitude of the participants towards the programme. This is consistent with the experiences of Delva-Tauili'ili (1995); Sathiparsad (1997) and Whittington and Morgan (1990) who found that family support and awareness of a programme secured their ongoing involvement. Commitment to the programme may have been further reinforced by the fact that the programme was sanctioned by the principal, the school governing body and the teachers at the school, and that the programme also formed part of the Learning Area: Life Orientation.

\section{COMMENTS ON THE PRESENT RESEARCH AND SUGGESTIONS REGARDING FUTURE RESEARCH}

It is recommended that, when further preventive programmes are developed and implemented, the evaluation component should be included to ensure that the prevention efforts have the desired effects. This is consistent with the White Paper on Social Welfare (1997), which views evaluation as an ongoing process to determine the appropriateness and economic viability of social welfare programmes.

A longitudinal study is recommended to ascertain the long-term effect of the Life Skills Programme. In addition, studies similar to those conducted by Gentry and Benenson (1993), Schmitz (1994) and Sliedrecht (1995), which included feedback from parents and teachers on the behaviour of the participants, could be beneficial in providing further information on the effects of the programme. 
Further research by multidisciplinary teams should be conducted in life skills education and training, and researchers should continue to gather and analyse data that would evaluate the effectiveness of life skills programmes.

\section{RECOMMENDATIONS}

A few recommendations are made on the basis of the findings and the conclusions drawn in this study:

- Given the principles of a multidisciplinary/sectoral approach and separation and service integration it is evident that the potential range of life skills trainers is wide and varied. Central to this, though, should be the team approach, with the team including a life skills coordinator and all the life skills trainers or educators who participate in the school's life skills programme. Every school should have a life skills co-ordinator. The team could consist of health workers, social workers and community workers, non-governmental organisation personnel, teachers, education support specialists, business enterprises, community leaders, parents and possible learners. However, the team of life skills trainers/educators would have to be co-ordinated to provide a cohesive curriculum guided by common principles and it should be outcomes-based;

- The curriculum for life skills education should be based on developmental principles so that appropriate life skills are facilitated at the appropriate life and career developmental stage, for the following reasons. Life skills education is a fundamental division of the Learning Area: Life Orientation. Life Orientation empowers learners to live meaningful lives in a society that demands rapid transformation. It is an integral part of education, training and development. The accomplishment of developmental tasks depends on the learner's mastery of the coping behaviours or life skills appropriate to the current developmental stage and associated developmental tasks. There are generally certain age ranges when certain life skills are optimally learned (compare Havighurst, 1972; Hurlock, 1978). By acquiring the relevant life skills during the appropriate stage of development, the individual achieves optimal functioning;

- Future life skills programmes should focus firstly on asking adolescents what kind of developmental challenges they would like help with to enable them to cope with these challenges. Secondly, adolescents should be asked to spell out specifically what coping life skills they would like to practise. Including adolescents in this way would help them to take ownership of the programme. Life Skills Programmes should also be presented for parents and interested community members;

- Programme evaluation should be integrated in all the programmes presented at schools. Programme evaluation measures the effectiveness of the programme and on this basis, guidelines could be provided for programme planning and decision making;

- Education support personnel (social workers, health workers, educators and psychologists) should provide services that focus on and involve the "whole school" or place of learning and the community. In this regard, training and professional development programmes should shift their focus away from a "deficit", problem-oriented philosophy of intervention, towards one in which support services focus on assets such as strengths, competencies and development. Courses should also offer an interpretative approach to inter-sectoral work, empowerment, capacity building, diversity, human rights, community development and institution-based team building and support (compare Donald \& Lazarus, 1995); 
- Building networks. In addressing any of the challenges discussed in this study, it is critical that the social worker should see him/herself as part of a team or "network" of other people. This network may consist of colleagues in the social worker's own organisation or from other organisations: teachers, principals, members of the school governing board, parents and other members of the community; and members of the helping professions such as doctors, nurses and psychologists. The social worker should be actively involved in building networks.

- Interdisciplinary collaboration: School social workers should collaborate with other professionals for two basic reasons: to exchange information and to co-ordinate services. An exchange of professional information is one way of increasing knowledge in areas that may not be familiar to the social worker, and of providing the means for professionals to help one another keep abreast of new information. Collaboration provides an opportunity to combine the input from various disciplines and to exchange points of expertise. Such collaborative efforts reduce professional isolation, help to build positive working relationships, and make services more comprehensive and effective. As interventions are focused on primary prevention and are designed to maximise interdisciplinary approaches, social workers should collaborate with teachers, clergy, police, health professionals and members of other services.

It is recommended for future group and class intervention programmes for Grade 7 learners of the senior phase of the General Education and Training Band that:

- $\quad$ as in the current study, a whole class should be selected for the Life Skills Programme as opposed to learners from different Grade 7 classes. If a whole class is selected this should, to a certain extent, increase the attendance rate. Irregular attendance at classes, learners dropping out of school and absenteeism are problems irrespective of the learning area. These problems are definitely more prevalent in some schools than in others;

- ideally, every Grade 7 learner in a school should be part of the programme. This would also intensify the effect of the programme, as all the learners would be involved in doing the same thing. It would also be better to implement the programme thoroughly in fewer schools than to implement the programme in many schools but with a low intensity;

- each of the themes in the Life Skills Programme could be divided into four to six sessions. This would mean that each of the themes could be extended to become a programme consisting of four to six sessions, giving the learners more opportunity to practise the life skills;

- a larger sample representative of the population should be used, so that generalisations to the greater population could be made with greater confidence;

- long-term follow-up evaluations should be made, in order to promote positive short-term programme outcomes that would endure; and in support of this,

- the intervention programme should also be evaluated with learners of different ethnic and socio-economic backgrounds;

- $\quad$ prior to the implementation of the programme the facilitator should make a presentation to all the staff/personnel informing them about the programme, the critical and in particular the specific outcomes. The school as a whole should support the project and give the facilitators the backing and encouragement they need. The school governing board and parents should also be informed and give their consent; 
- future programmes should include more learning in a service context. The learners should conduct or perhaps get involved in a community development project in order to practise their life skills.

\section{CONCLUSION}

The development and implementation of a life skills curriculum fits into the overall context of the development of education support services, namely social work, school health, specialised education, vocational and general guidance and counselling, and psychological services. The principle of service integration emphasises the need to view issues of development as interrelated. This principle necessitates an interdisciplinary/sectoral approach to curriculum development and implementation, including all of the above-mentioned education support services. The present study focuses on the role of social work, as part of education support services, in developing and implementing an outcomes-based life skills programme for the senior phase learner in the final year of primary school.

Life skills education is an expanding field of research. The reasons for the growth of life skills education include the following: it has a developmental and preventive emphasis; problems with living are widespread; and pressures are increasing for helper accountability.

The findings of this research show that a social worker can develop and facilitate a life skills programme effectively within the outcomes-based educational approach and be an active partner in education support services.

\section{REFERENCES}

ADKINS, W.R. 1984. Life skills education: A video-based counselling/learning delivery system. In LARSON, D. (ed). Teaching psychological skills. California: Brooks/Cole Publishing Company.

BRUENE-BUTLER, L. HAMPSON, J. ELIAS, M.J. CLABBY J.F. \& SCHUYLER, T. 1997. The improving social awareness - A problem solving project. In ALBEE, G.W. \& GULLOTA, T.P. Primary Prevention Works. London: SAGE Publications.

BRYMAN, A. 1990. Quantity and quality in social research. London: Unwin Hyman Ltd.

CHEETHAM, J. FULLER, R. MCIVOR, G. \& PETCH, A. 1992. Evaluating social work effectiveness. Buckingham: Open Press University.

COREY, M.S. \& COREY, G. 1992. Groups: Process and practice. Pacific Grove: Brooks/Cole Publishing Company.

DANIEL, W.W. \& TERRELL, J.C. 1995. Business statistics for management and economics. Boston: Houghton Mifflin.

DE JONG, T., GANIE, L., LAZARUS, S. \& PRINSLOO, E. 1995. Proposed general guidelines for a Life skills curriculum framework. In Gordon, A. (Ed.) Curriculum frameworks for the general phase of education. Johannesburg: Centre for Education Policy Development.

DELVA-TAUILI'ILI, J. 1995. Assessment and prevention of aggressive behavior among youths of colour: Integrating cultural and social factors. Social Work in Education, 17(2):83-91.

DEPARTMENT OF EDUCATION. 1997a. Curriculum 2005: Lifelong learning for the $\mathbf{2 1}^{\text {st }}$ Century. Pretoria: Department of Education. 
DePARTMent OF EDUCATION. 1997b. Senior Phase (Grades 7 to 9) Policy Document. CTP Books - Gov619/25000.

DEPARTMENT OF EDUCATION. 1999. Consultative Paper no 1 on Special Education: Building an Inclusive Education and Training System. Pretoria: Department of Education.

DEPARTMENT OF EDUCATION. 2002. Guidelines for outcome-based assessment in all grades in foundation, intermediate and senior phases implementing OBE. Circular 22. Gauteng Provincial Government. Johannesburg: Department of Education.

DONALD, D. \& LAZARUS, S. 1995. The development of education support services in South Africa the process of transition: goals and strategies. South African Journal of Education, 15(1):52-57.

DONALD, D., LAZARUS, S. \& LOLWANA, 1999. The development of education support services in South Africa the process of transition: goals and strategies. South African Journal of Education, 15(1):52-57.

DROWER, S. 1993. The contribution of group work in a changing South Africa. Social Work with Groups, 16(3):5-22.

FITZ-GIBBON, C.T. \& MORRIS, L.L. 1987. How to design a Program Evaluation. California: Sage Publications.

GABOR, P. 1993. SAMPLING. IN GRINELL Jnr., R.M. Social work research and evaluation. Illinois: F.E. Peacock Publishers.

GENTRY, D.B. \& BENENSON, W.A. 1993. School-to-Home transfer of conflict management skills among school-age children. Families in Society: The Journal of Contemporary Human Services, 74(2):67-73.

GRINNELL, R.M. \& WILliAMS, M. 1990. Social work research: A primer. Illinois: FE. Peacock Publishers, Inc.

HARRISON, W.D. 1994. The inevitability of integrated methods. In: SHERMAN, E. \& REID, W.J. (Eds.). Qualitative research in social work. New York: Columbia University Press.

HAVIGHURST, R.J. 1972. Developmental tasks and education. New York: David McKay Company, Inc.

HOPSON, B. \& SCALLY, M. 1986. Life skills teaching. London: McGraw-Hill Book Company.

HURLOCK, E.B. 1978. Developmental psychology. New York: McGraw-Hill.

HUYSAMEN, G.K. 1994. Methodology for the social and behavioural sciences. Pretoria: Sigma Press.

JORDAN, C., FRANKLIN, C. \& CORCORAN, K. 1993. Standardizing measuring instruments. In: GRINNELL (Jnr) R.M. Social work research and evaluation. Illinois: F.E. Peacock Publishers.

JARRETT, J. \& KRAFT, A. 1998. Statistical analysis for decision making. Boston: Allyn \& Bacon.

KING, J.A., MORRIS, L.L. \& FITZ-GIBBON, C.T. 1987. How to assess programme implementation. California: Sage Publications.

LOCKHART, R.S.1997. Introduction to statistics and data analysis for the behavioral sciences. New York: Freeman. 
MARLOW, C. 1993. Research methods for Generalist Social Work. California: Brooks/Cole Publishing Company.

MCKENDRICK, B. \& HOFFMANN, W. 1990. Towards the reduction of violence. In: McKendrick, B. \& HOFFMANN, W. (eds) People and violence in South Africa. Cape Town: Oxford University Press.

OLIVIER, C. 2001. Let's educate, train and learn outcomes-based. Ifafi: OBET Pro.

PATTON, M.Q. 1987. How to use qualitative methods in evaluation. Newbury Park, CA: SAGE Publications.

PATTON, M.Q. 1990. Qualitative Evaluation and research methods. Newbury Park, CA: SAGE Publications.

PICKWORTH, G. 1989. Life skills training and career development from a career guidance perspective. Pretoria: University of Pretoria. (Unpublished Masters Dissertation)

PIETRZAK, J., RAMLER, M., RENNER, T., FORD, L. \& GILBERT, N. 1990. Practical program evaluation: Examples form child abuse prevention. Newbury Park, CA: SAGE Publications.

ROOTH, E. 1997. Introduction to life skills: Hands-on approaches to life skills education. Hatfield: Via Afrika.

RSA, MINISTRY FOR WELFARE AND POPULATION DEVELOPMENT. WHITE PAPER FOR SOCIAL WELFARE. (Notice 1108 of 1997). Government Gazette, 386 (18166). Pretoria: Government Printer. 8 August 1997.

SATHIPARSAD, R. 1997. The development and evaluation of a conflict resolution programme: The school as context. Durban: University of Natal. (Unpublished Masters dissertation)

SCHMITZ, R. 1994. Teaching students to manage their conflicts. Social Work in Education, 16(2):125-128.

SCHMIDT, J.R., BROWN, P.T., \& WAYCOTT, A.M. 1988. Developing the individual: Life skills and family therapy. British Journal of Guidance and Counselling, 16(2):113-128.

SIEGEL, S. \& CASTELLAN, N.J. 1988. Nonparametric statistics for the behavioral sciences. New York: McGraw-Hill.

SLIEDRECHT, S. 1995. Life skills for adolescence: Evaluative research on the Quest Programme. Cape Town: University of Cape Town. (Unpublished Masters dissertation)

STEYN, A.G.W., SMIT, C.F., DU TOIT, S.H.C. \& STRASHEIM, C. 1994. Modern statistics in practice. Pretoria: JL van Schaik.

THACKERAY, M.G., FARLEY, O.W. \& SKIDMORE, M.A. 1994. Introduction to social work. Englewood Cliffs, New Jersey: Prentice-Hall Inc.

TSHIWULA, J.L. 1995. The development and evaluation of a preventive program for juvenile delinquency. Port Elizabeth: University of Port Elizabeth. (Unpublished Doctoral Dissertation)

VIJOEN, S. 1994. Strengths and weaknesses in the family life of black South Africans. Pretoria: Human Sciences Research Council (Report HG/MF-16). 
WEINBACH, R.W. \& GRINNELL JR, R.M. 1998. Statistics for social workers. New York: Longman.

WHITTINGTON, R. \& MORGAN, G. 1990. Teaching non-violence through Time Out: A curriculum for elementary school classrooms. Social Work in Education, 12(4):237-248. 